\title{
An Analysis of Socio-Economic Objectives of India's Tax Policy
}

\author{
KV Bhanu Murthy*
}

\begin{abstract}
The Indian tax system has successfully mobilised resources to finance administrative, welfare and developmental activities of public authorities. Besides being the main source of revenue for both Central and State Governments, it is an effective instrument to realise various socio-economic objectives of national policies. Further, tax policy is an important determinant of the investment climate in a country. This paper looks at the socio-economic objectives that the tax policy intends to achieve along with the steps taken to restructure the tax system in accordance with these objectives. Tax laws in India are replete with various exemptions, concessions, deductions, allowances, tax credits etc. to promote a host of desirable economic and social activities. These tax incentives encourage individuals and business entities to undertake activities desired by the government.
\end{abstract}

Keywords: Tax policy, Socio-economic objectives, Exemptions, Allowances.

\subsection{Introduction}

The Indian tax system has undergone major structural changes since Independence in 1947. It has become comprehensive and complicated over the years. It has successfully mobilised resources to finance administrative, welfare and developmental activities of public authorities. Besides being the main source of revenue, both for the Central and State Governments, it is an effective instrument to realise various socio-economic objectives of national policies. Restructuring of the tax system has constituted a major component of fiscal reforms initiated since 1991. The main focus of the tax reforms has been on simplification and rationalisation of both direct and indirect taxes with the objective of augmenting revenues and removing anomalies in the tax structure. Tax reforms of recent years have brought the tax system much closer to international tax practices.

*Professor, Department of Commerce, Delhi School of Economics, University of Delhi. 
Furthermore, tax policy — as an integral part of the fiscal policy of a country - is an important determinant of the investment climate in a country. Rates of direct taxes determine the incentives to work, save and invest, while the level and structure of indirect taxes influences the aggregate demand and thus the scale of operations on the one hand and relative prices of different goods and services on the other. Concerted efforts to simplify the tax system, moderate tax rates and avoid cascading of taxes have improved the investment climate in India.

Tax laws in India are replete with various exemptions, concessions, deductions, allowances, tax credits etc. to promote a host of desirable economic and social activities. These tax incentives encourage individuals and business entities to undertake activities desired by the government.

\subsection{Rationale for providing tax incentives}

Tax incentives, an integral part of tax systems the world over, are designed to promote a wide spectrum of socio-economic objectives. If judiciously used, they can become an effective tool of economic change on desired lines.

Individuals: Tax incentives related to individuals promote equity. Examples in this category are exemption of an initial slice of income from tax, and allowances related to dependants. Two individuals with equal incomes may have to support families of different sizes and it would be justifiable to extract less from the individual with a larger family size. However, these considerations are more relevant at low income levels. Apart from equity, promotion of individual savings, contributions towards charitable purposes are other commonly promoted objectives. Tax incentives for these purposes are usually in the form of deductions from taxable base or tax credits against savings/investments in specified channels.

Business Organisations: Tax incentives related to business sector are meant to induce business enterprises to undertake activities which they would otherwise shirk. Thus, these incentives are designed to encourage investment in general or in preferred industries or in preferred geographical areas (industrially backward regions). Such incentives take a variety of forms such as investment allowance, accelerated depreciation of fixed assets, and exemption of profits from tax for specified initial years of business (tax holiday).

General Purpose Incentives: These are meant to provide flexibility to the tax system to deal with changing market situations. They are used as a corrective mechanism to stabilise demand, production, and profits of different industries. Thus, tax incentives may be given to boost sluggish demand for idle-capacity industries. Similarly, incentives are given for the promotion of sports, cultural and social welfare organisations. Tax incentives are also given to promote exports, scientific research, and desired type of technology (e.g. labour-intensive 
technology in labour surplus economies). Thus, a tax system, apart from raising revenue, may be used to promote activities deemed vital by society, though it is controversial as to which activities are vital and require governmental support.

\subsection{Health, Education and Housing}

Improvement in the health status of the population has been one of the major thrust areas in social development programmes of India since Independence. Over the past six decades, India has built up a vast health infrastructure and manpower at primary, secondary and tertiary care levels in the government, voluntary and private sectors manned by professionals and para-medicals. India has invested massive amounts under the successive Five Year Plans in medical education, training and research which has ensured large manpower from the super-specialists to the auxiliary midwives.

Income Tax Act, 1961 allows deductions from gross total income in respect of the following: (a) deduction in respect of medical insurance premia (Section 80D), (b) deduction in respect of medical treatment and deposit made for maintenance of handicapped dependents (Section 80DD), and (c) deduction in respect of medical treatment (Section 80DDB).

Education has been a thrust sector ever since India attained Independence in 1947. Right from the inception of planning, the crucial role of education in economic and social development has been recognised and emphasised. Efforts to increase people's participation in education and to diversify educational programmes in order to promote knowledge and skills required for nation-building have characterised successive Five Year Plans. Despite a series of problems that the country faced soon after Independence, it has been possible to create a vast educational infrastructure in terms of large enrolments and teaching force and massive capabilities for management, research and development. Under Section 80E of the Income Tax Act, 1961, deduction from gross total income is allowed in respect of interest on loans taken for higher education.

Housing is an activity that is typically labour intensive and, therefore, fits in well with the pattern of development envisaged for India. The provision of shelter is a basic need which must be met. Housing construction also creates much-needed employment for the unskilled and, therefore, income for the relatively poor. Income Tax Act, 1961 allows deduction from gross total income in respect of home loan repayment (Section $80 \mathrm{C}$ ) and in respect of interest on loan taken for residential house property (Section $80 \mathrm{EE})$. 


\subsection{Tax Incentives for Infrastructure Development}

The magnitude of resources needed for the infrastructure sector is of such dimensions that the requisite investments would need to be funded eventually by raising resources from the domestic and international capital markets. In the initial stages, support from the financial institutions and commercial banks could be relied upon to a degree. However, there is clearly a limit to the extent of resources that could be accessed through the existing financial system.

In a liberalised economic regime, it is inevitable that all sectors would need to compete for capital. It is only those sectors that provide attractive rates of return that would eventually be successful in this resource-raising exercise. Projects in the infrastructure sector would need to compete for resources from the capital market and be perceived by investors as being as attractive as conventional manufacturing projects. It is, thus, desirable that such projects be brought to the centre stage of capital market flows to attract investments from a wider pool of lenders, including financial institutions, the corporate sector and in the medium term, retail investors.

Initial encouragement is needed from the Government to induce a sectoral flow of savings to the infrastructure sector. Once the initial clutch of projects of this genre is established successfully on commercial principles, fiscal benefits may no longer be needed to the same degree. It can be demonstrated that the economic rate of returns from infrastructure projects is well in excess of the financial rate of returns. The higher economic rates of return stem from monetary as well as social factors including reduction in pollution levels, savings in time, and the ancillary economic activities that such projects generate.

The case for attracting FDI is significantly strengthened through the provision of an adequate level of infrastructure. There is thus adequate economic rationale for encouraging the sponsorship of infrastructure projects and to facilitate investments in this sector.

The commercialisation of infrastructure projects is typically formulated on the basis of recovery of investments through a system of user charges. Such user charges bear a direct relation to the specific benefits that the facility provides to the user. For example, a toll road would provide the user savings in terms of time, fuel, vehicular maintenance etc. The user would then compare the user charge to the benefits and savings realised. The level of user charges does not encompass the secondary and tertiary levels of economic benefits stemming from the implementation of the project and which flow to society at large. Typically, such benefits are a multiple of project cost. These externalities arise without government contributing to project expenditure.

To this extent, it can be argued that the provision of fiscal benefits is not a subsidy, 
but a contribution from government that is supported by benefits accruing from the externalities of the project. In the absence of such contribution, the private investment flows may not take place at all. Thus, such fiscal benefits have the effect of mobilising private resources in the financing of projects.

The fundamental premise of commercialisation is a shift of the burden of funding from government to a structure where public savings are channelised to create infrastructure facilities. Significant growth in the Indian capital market and the appetite of investors for financial assets received a fillip after specified fiscal incentives were provided by government for investments in the shares of newly promoted companies. Public savings were thus channelised towards the creation of productive capacities. A similar initiative is needed today from government to create a shift in savings towards investment in infrastructure.

Infrastructure projects in the targeted sectors are not readily amenable to attracting public savings. Typically, these projects have a long gestation period and are not readily understood by retail and other investors. Hence, there is a need to position such investments as an attractive option vis-à-vis other competing opportunities. An investor today needs an inducement to shift a part of his portfolio from conventional projects to projects in the targeted sections. There is hence a need to consider the provision of specific fiscal benefits to infrastructure projects that are deemed to be of public interest.

Once a project is defined to an adequate degree, an array of fiscal benefits could be considered on a project-specific basis. The array of benefits could be defined under four generic heads:

1. Tax-free status for the project entity.

2. Benefits to the sponsor.

3. Benefits to the wholesale investor.

4. Benefits to the retail investor.

3.1 Income Tax Incentives under Section 80-IA: Section 80-IA of Income Tax Act, 1961 provides for deduction from profits and gains of industrial undertakings/enterprises engaged in infrastructure development. The deduction is available to the following:

1. An enterprise owned by a company or consortium of companies or by an authority or a board or a corporation or any other statutory body, carrying on the business of: (i) developing, (ii) operating and maintaining, or (iii) developing, operating and maintaining, any infrastructure facility under an agreement with the Central/State Government or a local authority etc. which starts operating and maintaining the infrastructure facility on or after April 1, 1995. Infrastructure facility means the following: (a) a road including toll road, a bridge or a rail system, (b) a highway 
project including housing or other activities being an integral part of the highway project, (c) a water supply project, water treatment system, irrigation project, sanitation and sewerage system or solid waste management system, and (d) a port, airport, inland waterways or inland port or navigational channel in the sea.

2. An undertaking which starts providing telecommunication services (basic or cellular), including radio paging, domestic satellite services or network of trunking and electronic data interchange services, during April 1, 1995 to March 31, 2005.

3. (a) An undertaking which develops or develops and operates or maintains and operates an industrial park notified by the Ministry of Commerce and Industry, during April 1, 1997 to March 31, 2011. (b) An undertaking which develops, develops and operates, or maintains and operates a special economic zone notified by the Government for the period April 1, 1997 to March 31, 2006.

4. An undertaking set up in any part of India for the generation, or generation and distribution of power, which begins to generate power during April 1, 1993 to March 31, 2014.

5. An undertaking which starts transmission or distribution by laying a network of new transmission or distribution lines, during April 1, 1999 to March 31, 2014.

6. An undertaking which undertakes substantial renovation and modernization of the existing network of transmission or distribution lines, during April1, 2004 to March 31, 2014.

7. An undertaking owned by an Indian company (formed before November 30, 2005 and notified before December 31,2005) and set up for reconstruction or revival of a power generating plant, which begins to generate or transmit or distribute power before March 31, 2011.

Amount of Deduction: The deduction is allowable for 10 consecutive assessment years (A.Ys) as under:

(i) In the case of an undertaking providing telecommunication services

For the initial 5 A.Ys: 100 percent of the profits and gains

For the next 5 A.Ys: 30 percent of the profits and gains

(ii) In the case of other eligible undertakings and enterprises.

For 10 consecutive A.Ys: 100 percent of the profits and gains

The assessee may opt for any 10 consecutive years out of 15 years beginning with the year in which the undertaking starts the eligible activity.

In the case of an enterprise providing an infrastructure facility (except a port, airport, inland waterways, inland port or navigational channel in the sea), the assessee may opt for any 10 consecutive years out of 20 years beginning with the year in which it begins providing such infrastructure facility. 
Experts have recommended several changes to be made in Section 80-IA which are crucial to the commercialisation of the country's infrastructure services.

1. The Section gives a restricted meaning to 'infrastructure facility' covering infrastructure relating to transport, such as surface transport, air, waterways and rail. Infrastructure, however, includes other services such as land area development, establishment of township, water and sewerage systems, social welfare like education and healthcare. These sectors have not been included in the definition. Therefore, the scope of infrastructure facility should be expanded to include all these sectors.

2. The Section also specifies that the infrastructure facility should be new. Accordingly, it may not include projects which involve remaking or expansion. Most infrastructure projects would involve acquisition of existing facility to meet the increased demands, e.g. a surface transport project could involve remaking the existing road and extending or converting two lanes into four lanes. Similarly, water and sewerage projects could involve taking over the existing distribution system or treatment facilities and building additional facilities to augment increased requirements. In most cases, it is necessary to capture revenues from existing facilities to make the expansion viable. Hence, the scope of definition should be extended to include projects involving expansion or remaking of existing facilities.

3. The Section requires the infrastructure facility to be owned by an enterprise. In many infrastructure projects, it may not be feasible to own all the facilities. As a financing strategy some of the equipment may be procured under a leasing or other financing arrangement. It is, therefore, necessary to clarify that the scope of this section extends to include cases where part of the infrastructure facility is procured under a lease or any other financing arrangement.

4. The benefits under the Section are available only to enterprises owned by a company - or a consortium of companies - incorporated in India. Given the nature of infrastructure projects, it would be necessary to have access to technological and financial participation from international sources. It is therefore necessary to extend the benefits to all enterprises including those where majority of shareholding is held by foreign companies.

5. In most infrastructure projects, it would be necessary to consider the grant of rights from the government to develop ancillary facilities such as land for building townships, developing adjacent areas or operating utilities like petrol pumps, restaurants etc. The current meaning of Section 80-IA defines tax holiday on profits derived from infrastructure business. Accordingly, the revenue authorities could argue that revenues or profits derived from such ancillary development are not 
eligible for tax holiday. However, in that case, the project would not be in a position to claim the tax holiday benefit on income purely derived from the user charges of infrastructure facilities because these revenues will not generate significant profits. A clarification should be provided in Section 80IA stating that the entire project income inclusive of income from any ancillary development will qualify for tax holiday benefit.

\subsection{Tax Concessions for Labour Welfare}

\subsection{Income Tax Concessions}

The Indian Income Tax Act, 1961, provides various incentives for promoting labour welfare activities. Section 10 of the Act describes incomes which are absolutely exempt from the purview of income tax, i.e. tax free incomes. These exemptions are meant to serve various socio-economic objectives through the medium of tax policy. The important types of income altogether excluded from the scope of tax under various clauses of Section 10 of the Act and which have bearing on labour welfare are the following.

A. Leave Travel Concession: Value of any leave travel concession or assistance received by an employee from the employer for himself and his family in connection with his proceeding on leave to any place in India is exempt from tax [Section 10(5)]. For the purpose of this section, 'family' in relation to an individual means: (a) the spouse and children of the individual, and (b) the parents, brothers and sisters of the individual dependent on him. Furthermore, the amount exempt under this section can in no case exceed the expenditure actually incurred for the purpose of such travel.

B. Death-cum-Retirement Gratuity: Exemption from tax is available to gratuity payments up to the following prescribed limits [Section 10(10)].

1. In the case of Government employees, any death-cum-retirement gratuity received by Government employees is wholly exempt from tax. Government employees mean employees of Central Government, State Governments, and Local Authorities.

2. In the case of employees covered by the payment of Gratuity Act, 1972, any gratuity received by an employee is exempt from tax to the extent of the least of the following: (a) 15 days salary (based on salary last drawn) for every completed year of service or part thereof in excess of six months, (b) Rs. 1,00,000 or (c) gratuity actually received.

3. In the case of any other employee, any gratuity received by him is exempt from tax to the extent of the least of the following: (a) Rs. 10 lakh, (b) half month's salary for each completed year of service, or (c) gratuity actually received. 
C. Commutation of Pension: Pension received by a Government employee as well as non-Government employee is taxable as salary under Section 15 of the Act. However, any commuted pension received by a Government employee is wholly exempt from tax under Section 10(10). In the case of payment in commutation of pension received by a non-Government employee, the following provisions apply: (a) where the employee receives gratuity, the commuted value of one-third of the pension is exempt from tax, and (b) in any other case, the commuted value of one-half of such pension is exempt from tax. It may be noted that pension is a periodic payment received by an employee after his retirement while commuted pension is a lump sum payment in lieu of periodic pension payment.

D. Leave Salary: Under Section 10(10AA), any amount received by an employee of Central/State Government as the cash equivalent of leave salary in respect of period of earned leave at his credit at the time of his retirement is exempt from tax. In the case of a non-Government employee, leave salary is exempt from tax to the extent of the least of the following: (a) cash equivalent of the leave salary in respect of the period of earned leave to the credit of employee at the time of his retirement or (b) eight month's average salary or (c) the amount specified by the Government (Rs. 2,40,000 if the date of retirement is on or after July 1, 1997), or (d) leave encashment actually received at the time of retirement.

E. Retrenchment Compensation: Under Section 10(10B), compensation received by a workman at the time of retrenchment is exempt from tax to the extent of the lower of the following: (a) An amount calculated in accordance with the provisions of Section $25 \mathrm{~F}$ (b) of the Industrial Disputes Act, 1947 (these provisions entitle a workman to retrenchment compensation equal to 15 days average pay for every completed year of service or any part thereof in excess of six months), or (b) such amount (not being less than Rs. 5,00,000) as notified by the Government.

F. Voluntary Retirement Compensation: Under Section 10(10C), compensation received by an employee at the time of voluntary retirement is exempt from tax subject to certain conditions.

G. Income of Fund Established for Welfare of Employees: Section 10(23AAA) provides exemption from tax on any income received by any person on behalf of a fund established for the welfare of employees or their dependents and of which fund such employees are members.

H. Income of Trade Unions: Under Section 10(24), any income chargeable under the heads income from house property and income from other sources of a trade union is exempt from tax. The trade union must be registered under the Indian Trade Union Act, 1926 formed primarily for the purpose of regulating the relations between workmen and 
employers. Similarly, tax exemption is available to an association of trade unions.

I. Health Insurance of Employees: Under Section 36(1), an employer can claim deduction in respect of premia paid by him by cheque for insurance on the health of his employees.

J. Bonus to Employees: Under Section 36(1), bonus or commission paid to an employee is allowable as deduction subject to certain conditions.

K. Employer's Contribution to Gratuity Fund: Under Section 36(1), employers' contribution towards an approved gratuity fund created by him exclusively for the benefit of his employees under an irrevocable trust is allowable as deduction.

L. Family Planning Expenditure: Any bonafide expenditure incurred by a company for the purpose of promoting family planning among its employees is allow-able as deduction. If such expenditure is of a capital nature, one fifth of it is allowable as deduction for the year in which it was incurred and the balance is deductible in equal instalments in the next four years [Section 36(1)(ii)].

M. Provident Fund: Employer's contribution towards recognised provident fund or an approved superannuation fund is allowable as deduction subject to certain limits [Section 36 (1)(iv)].

\subsection{Wealth Tax Concessions}

It is notable that Indian Wealth Tax Act, 1957, also contains provisions which facilitate the employment of labour. One such provision exempts from wealth tax the value of any building belonging to the assessee if the building is exclusively used for the purpose of the residence of persons employed by him in any plantation or industrial undertaking belonging to him. The exemption is subject to the condition that the annual salary of each such employee is Rs. 10,000 or less [Section 5(i)(XXXa)].

\subsection{Excise Duty Concessions}

Excise exemptions and concessions are particularly important in promoting labour-intensive technology and small-scale industries. Central excise law contains provisions the sole objective of which is employment generation. Products of a number of industries are exempt from excise duty if they are manufactured without the aid of power. Duty differentials have been used to discourage mechanisation in certain industries.

Similarly, concessions are available to the handloom sector of the textile industry. Processed khadi cloth woven on handloom wholly from hand spun cotton yarn or in admixture with similar silk and/or woollen yarn enjoys full exemption since 1969. Cotton fabrics manufactured on handlooms and processed by a factory owned by a 
registered handloom co-operative society enjoy full exemption from duty.

The Expert Committee on Tax Measures to Promote Employment, 1980, made estimates of the annual cost of protecting or subsidising employment through concessions in excise duties. It found that the annual cost of protecting or subsidising employment through concessions in excise duties was Rs. 523 per full-time worker in the handloom industry, Rs. 881 in khandasari, and Rs. 2,669 in the cottage sector of the match industry. (Government of India, 1980).

In line with Government's policy of encouraging small-scale industries, a wide range of concessions and exemptions from excise duty is available to small producers to enable them to stand in competition with large-scale manufacturers. Also, relatively simple and concessional procedures are followed for the assessment and collection of excises from the small-scale sector.

\subsection{Fiscal and Financial Incentives for Protection of Environment}

\subsection{Income Tax Concessions}

These are as under:

A. Concessions under Section 35-CCB: Following types of concessions under Section 35-CCB of the Indian Income Tax Act, 1961 are available to taxpayers carrying on business or profession.

a) Sums paid by a taxpayer to any association or institution, which has as its object the undertaking of programmes of conservation of natural resources, to be used for such programmes, are allowed as deductions in the computation of taxable profits. The deduction under this provision is not allowed unless the association or institution, as also the programme of conservation of natural resources for which such sums are paid have been approved by the prescribed authority (i.e. Secretary, Department of Environment, Government of India). The prescribed authority will not approve an association or institution for this purpose for more than three years at a time.

b) Sums paid to an association or institution which has as its object the undertaking of any programme of afforestation are allowed as deduction in the computation of taxable profits. For this purpose, both the association/institution and the programme of afforestation will have to be approved by the prescribed authority.

c) Any payment made to a notified Fund for Afforestation will also qualify for deduction under Section 35-CCB. A National Fund for Afforestation and Wasteland Development has been set up. Donations from individuals as well as corporate/noncorporate bodies are eligible for 100 percent deduction.

B. Long-term Capital Gains: Under Section 54-G of the Indian Income Tax Act, 
1961, long-term capital gains made from the transfer of machinery, plant, land, and building etc., forming part of an industrial undertaking are exempt from taxation where transfer is effected for the shifting of the industrial undertaking from an urban area to any other area, provided these are reinvested in approved relocation schemes within one year before or three years after the date of transfer. The amount of exemption is equal to the amount so utilised or the amount of capital gains, whichever is less. Apparently, the purpose of this exemption is to encourage industries to shift out of congested urban areas to reduce pollution and other hazards.

C. Depreciation Allowance: Depreciation allowance at the rate of 100 percent is granted for installing pollution control equipment. Pollution control equipment has been given the benefit of accelerated depreciation for corporate tax computation. In the 1993-94 budget, 100 percent of written down capital cost of such equipment is exempted from the corporate tax.

In his 1998-99 budget, the Finance Minister allowed 100 percent deduction, subject to a ceiling of Rs. 5 lakh, to undertakings engaged in the collection or processing of biodegradable waste. Similarly, activities which encourage the production of bacteria induced fertilisers were made eligible for 100 percent deduction under Section 35-AC of the Income Tax Act.

\subsection{Excise Duty Concessions}

a) Production of building material using fly ash and phospho-gypsum in 25 percent or more quantities as raw material is exempt from excise duty.

b) Bricks and tiles manufactured using red mud in 25 percent or more quantities as raw material are exempt from excise duty.

c) Excise duty at the low rate of 5 percent is levied on manufactured goods that are used for pollution control.

\subsection{Customs Duty Concessions}

Customs waive off is provided by the Government to encourage the installation of appropriate pollution abatement equipment.

a) Exemption from customs duty is allowed on the import of equipment, machinery, and capital goods required for the production of building materials, using fly ash/phosphor-gypsum, such as bricks, light weight aggregates and light weight concrete elements.

b) Customs duty is levied at the reduced rate of 35 percent on equipment and spares for pollution control.

c) Customs duty is levied at the reduced rate of 25 percent on kits required for 
conversion of petrol driven vehicles to compressed natural gas driven vehicles.

As a measure of environmental protection, the Finance Minister in his 1998-99 budget reduced the import duty on sawn wood and certain other varieties of wood from 30 percent to 25 percent, on bio-pesticides (which are eco-friendly) from 30 percent to 5 percent and on membrane electrolysers and parts from 25 percent to 10 percent.

\subsection{Financial Assistance}

It is provided in the following manner:

a) Under the Scheme for Promotion of Common Effluent Treatment Plants in clusters of small industries (aided by World Bank), financial assistance towards capital investment up to 50 percent or Rs. 1 crore, whichever is less, is given as a subsidy.

b) Central Government assistance up to 40 percent or a maximum of Rs. 1.5 crore is provided for setting up demonstration projects in the areas of waste minimisation, clean technologies, and waste recycling.

c) Assistance is provided to large and medium scale units to install effluent treatment plants aimed at waste minimisation, resource recovery, and pollution abatement.

The policy of the Government of India on environment has been guided by the principles of Agenda 21 which was adopted at the Earth Summit in Rio de Janeiro in June 1992 and which aims at integrating environmental imperatives with developmental aspirations. The principles of Agenda 21 find reflection in the policy statements of the Government of India on forestry, abatement of pollution, national conservation strategy and environment and development. India is a signatory to the Montreal Protocol for phasing out ozone depleting substances, the Convention on biological diversity and other international treaties.

In India, Government has taken various measures, preventive as well as promotive, to improve environment. However, it has not used pollution taxes for environmental protection. The currently levied cess on the consumption of water for industrial activities is not a pollution tax. Its objective is to raise revenue for the pollution control boards but not to control pollution. Pollution taxes are levied in many countries with public support. Thus, Brazil, Colombia, and Venezuela charge a forestry tax when tree harvesting is not compensated by equivalent reforestation. Similarly, landfill $\operatorname{tax}^{1}$ is imposed in many Western countries including Britain.

The policy in India has focused on providing pollution subsidies (i.e. tax concessions) to industries in various forms. These subsidies have not proved effective in controlling pollution. They do not force the polluters, as do pollution taxes, to adopt pollution abatement technologies. Similarly, there has been a lack of an appropriate price policy for the use of natural resources. 


\section{Endnote}

1. Landfill tax is a fiscal innovation of recent origin, necessitated by world-wide concern for depleting environmental resources. It is a tax on producers who dump their industrial waste in the landfills. It can also be levied on municipal authorities for dumping city waste in the landfills. Such a tax, it is argued, encourages recycling and treatment of various types of waste by producers and local authorities. By following proper waste management practices, polluters can avoid the tax and hence contribute to cleaner environment. The tax, thus, acts as a deterrent on dumping industrial and other wastes in the landfills. The tax may distinguish between active waste and inert waste, the former being more harmful and therefore taxed at a higher rate. For example, in Britain (where the tax was introduced in 1996) active waste is taxed at $£ 10$ per tonne as compared to $£ 7$ per tonne for inert waste. The tax has gained popularity in the West and needs to be adopted in India where concern for environmental degradation is growing day by day.

\section{Reference}

Government of India, Ministry of Finance. (1980). Report of the Expert Committee on Tax Measures to Promote Employment (Chairman: V.M. Dandekar). 